\title{
Response of soil fungi and biological processes to crop residues in no-tillage system ${ }^{1}$
}

\author{
Priscila de Oliveira ${ }^{2}$, Adriano Stephan Nascente ${ }^{3}$, \\ Enderson Petrônio de Brito Ferreira ${ }^{3}$, João Kluthcouski ${ }^{2}$, Murillo Lobo Junior ${ }^{3}$
}

\begin{abstract}
Soil management and crop rotation can directly affect the soil microbial community. This study aimed at determining soil quality indicators and soilborne fungi in a no-tillage system. A randomized blocks design, in a $3 \times 2$ factorial arrangement, was used. Three cover crops (palisade grass, millet and common bean) provided straw and root residues to the following crops of corn and soybean. The common bean-soybean sequence provided little soil covering and higher metabolic quotient and soil basal respiration and total enzymatic activity, as well as a general increase of soilborne fungi. The principal component analysis revealed that $76.61 \%$ of the variance can be explained by the three first components, with cover crops, soil basal respiration and metabolic quotient regarded as the main qualitative and quantitative sources of variance in the first component. Carbon from the microbial biomass was the soil quality indicator best correlated to crop yield and negatively correlated to Fusarium solani density. The Rhizoctonia solani population was correlated with higher metabolic quotient and soil total enzymatic activity and basal respiration. The palisade grass crop favored soil fungistasis and enhancement of antagonist Trichoderma spp. populations. The multivariate approach demonstrated the association of soil fungi with soil quality indicators, as well as a higher influence of cover crops on the variance observed, in comparison to cash crops.
\end{abstract}

KEY-WORDS: Microbial biomass; basal respiration; suppressive soils.

\section{INTRODUCTION}

Sustainable crop management involves the careful choice of cover crops that avoid organic matter loss and population growth of soilborne harmful microorganisms. The soil microbial community presents a vast array of fungal and

\section{RESUMO}

Resposta de fungos e processos biológicos do solo a resíduos vegetais em sistema plantio direto

O manejo do solo e a rotação de culturas podem afetar diretamente a comunidade microbiana do solo. Objetivou-se determinar indicadores de qualidade e fungos habitantes do solo, no sistema plantio direto. Utilizou-se delineamento em blocos casualizados, em esquema fatorial $3 \times 2$. As três espécies de cobertura utilizadas foram braquiarão, milheto e feijão-comum, que forneceram palha e resíduos de raízes para o milho e a soja. A sequência feijão-comum + soja proporcionou pouca cobertura do solo, maior quociente metabólico e respiração basal e atividade enzimática total do solo e aumento geral de fungos de solo. A análise de componentes principais teve $76,61 \%$ da variância explicada pelos três primeiros componentes, com as culturas de cobertura, a respiração basal do solo e o quociente metabólico considerados as principais fontes qualitativas e quantitativas de variância no primeiro componente. $\mathrm{O}$ carbono da biomassa microbiana foi o indicador de qualidade do solo melhor correlacionado com o rendimento das culturas, e negativamente correlacionado com a densidade de Fusarium spp. A população de Rhizoctonia solani foi correlacionada com maior quociente metabólico e atividade enzimática total e respiração basal do solo. $\mathrm{O}$ cultivo do braquiarão favoreceu a fungistase no solo e aumento das populações do antagonista Trichoderma spp. Aavaliação multivariada demonstrou a associação de fungos de solo com indicadores de qualidade do solo, bem como maior influência das plantas de cobertura sobre a variância observada, em comparação com as culturas de verão.

PALAVRAS-CHAVE: Biomassa microbiana; respiração basal; solos supressivos.

bacterial species, including soil organic matter decomposers (Moreira \& Siqueira 2006) and root pathogens such as Rhizoctonia solani and pathogenic formae specialis of F. oxysporum (Van Bruggen \& Semenov 2000).

The saprophytic survival of these pathogens complicates disease management in host crops such

1. Manuscript received in Oct./2015 and accepted for publication in Mar./2016 (http://dx.doi.org/10.1590/1983-40632016v4638374).

2. Empresa Brasileira de Pesquisa Agropecuária (Embrapa Cerrados), Planaltina, DF, Brazil.

E-mails: priscila.oliveira@embrapa.br, joão.kluthcouski@embrapa.br.

3. Empresa Brasileira de Pesquisa Agropecuária (Embrapa Arroz e Feijão), Santo Antônio de Goiás, GO, Brazil. E-mails: adriano.nascente@embrapa.br, enderson.ferreira@embrapa.br, murillo.lobo@embrapa.br. 
as common bean (Phaseolus vulgaris L.) and soybean [Glycine $\max$ (L.) Merr.]. Theoretically, the severity of root rots and vascular wilts is proportional to inoculum density increase, in response to loss of general microbial biomass and microbial activity (Garbeva et al. 2004). Monoculture and short crop rotations decrease microbial diversity and activity (Anderson \& Domsch 1989).

Sustainable practices to avoid yield losses include the boost of antagonists and biological processes to promote soil suppressiveness (Anees et al. 2010). Despite many goals on soil health reported with composts and other practices (Veeken et al. 2005), the recovery of infested fields remains challenging, especially in tropical regions where two or three annual harvests favor the buildup of a complex population of soil pathogens (Termorshuizen et al. 2006).

The conservation of helpful species and beneficial biological processes is essential to a positive balance against pathogenic microorganisms in soil, aiming toward a sustainable agricultural management. Some biochemical and biological variables can be employed as sensitive markers of environmental changes, concerning land use, and are potential tools to predict soil quality and support decision-making on crop management (Bonanomi et al. 2010). Since microbiological communities in the soil have an important role in crop development (Moreira \& Siqueira 2006), it is necessary to know the impacts of agronomic practices on these communities to protect and enhance beneficial microorganisms.

Consequently, the assessment of soil key species to biological control provides relevant information that may support sustainable agricultural systems. Such assessment includes investigations on cropping sequences, cultural practices, chemical and organic pathogen control, climatic variables, microbial components and overall microbial activity in the rhizosphere, in comparison with bulk soil (Odum 1985, Pankhurst et al. 1995, Knupp \& Ferreira 2011).

Many ecological relationships on soil have been described by variables assigned as quality indicators, assessed according to their chemical, physical and biological nature (Weller et al. 2002). Mulch and root residues provided by conservation tillage are important sources of nutrients and energy for the soil microbial community (Ferreira et al. 2011). In no-tillage agricultural systems, mulch and organic inputs enhance the microbial biomass and nutrient storage, supporting increased yields in a sustainable way (Ferreira et al. 2010, Kaschuk et al. 2010).

Agricultural systems are complex. Despite the importance of individual variables, it is necessary to have a holistic view of the impacts on relevant processes to the agroecosystem (Pankhurst et al. 1995, Knupp \& Ferreira 2011). There are still few reports concerning the relationships among soil quality indicators, inoculum density of biocontrol agents and root pathogens in tropical soils. Therefore, this study aimed at assessing the effects of different crop rotations under no-tillage system on some attributes of the soil biological quality indicators and their association to pathogenic and beneficial soil fungi.

\section{MATERIAL AND METHODS}

The experiment was carried out in Santo Antônio de Goiás (16 $28^{\circ} 00^{\prime}$ 'S, 49 $9^{\circ} 17^{\prime} 00^{\prime \prime} \mathrm{W}$ and $823 \mathrm{~m}$ of altitude), Goiás State, Brazil. According to the Köppen classification system, the site has an "Aw" climate, tropical Savannah, mesothermal. The average annual temperature ranges from $20.6{ }^{\circ} \mathrm{C}$ to $24.2^{\circ} \mathrm{C}$, with $1,485 \mathrm{~mm}$ of rainfall.

The soil was classified as a dark red Dystrophic Oxisol with clayey texture. Prior to the experiment, soil samples were collected for chemical analysis at the $0-20 \mathrm{~cm}$ depth layer, with the following results: $\mathrm{pH}=6.1 ; \mathrm{Ca}=2.6 \mathrm{cmol}_{\mathrm{c}} \mathrm{dm}^{-3} ; \mathrm{Mg}=0.9 \mathrm{cmol}_{\mathrm{c}} \mathrm{dm}^{-3}$; $\mathrm{Al}=0.0 \mathrm{cmol} \mathrm{dm}^{-3} ; \mathrm{H}^{\mathrm{c}}+\mathrm{Al}=5.1 \mathrm{cmol} \mathrm{dm}^{\mathrm{c}} ; \mathrm{P}=$ $5.8 \mathrm{mg} \mathrm{dm}{ }^{-3} ; \stackrel{\mathrm{c}}{\mathrm{K}}=218 \mathrm{mg} \mathrm{dm}^{-3} ; \mathrm{Cu}=3.6 \mathrm{mg} \mathrm{dm}^{-3}$; $\mathrm{Zn}=4.2 \mathrm{mg} \mathrm{dm}^{-3} ; \mathrm{Fe}=33 \mathrm{mg} \mathrm{dm}^{-3} ; \mathrm{Mn}=51 \mathrm{mg} \mathrm{dm}^{-3}$. Soil organic matter was estimated in $23 \mathrm{~g} \mathrm{dm}^{-3}$.

The experimental area was cropped in 2005/2006, adopting the "Santa Fé" system, a corn (Zea mays L.) and palisade grass [Urochloa brizantha (C. Hochstetter ex A. Rich.) R. Webster] intercropping highly used in Brazil for crop-livestock integration and no-tillage. Afterwards, the entire area was cropped with common bean in the fall/winter of 2006, followed again by the "Santa Fé" system in the summer of 2006/2007.

The layout of the experiment was a complete randomized blocks design with four replications, disposed in a $2 \times 3$ factorial scheme. Treatments consisted of mulch and root residues provided by the cover crops used [palisade grass, millet (Pennisetum glaucum (L.) R. Brown) and common bean] and two spring/summer crops (corn and soybean). The plot size was $20 \mathrm{~m}^{2}(4 \mathrm{~m} \times 5 \mathrm{~m})$. 
In the fall/winter of 2007, the field was divided to establish common bean, millet and palisade grass. Autumn-seeded crops were grown under sprinkler irrigation, and cultivation procedures followed regional recommendations for each specific species. Common bean was manually harvested at 90 days after planting, and grasses were herbicide-burned with $6 \mathrm{~L} \mathrm{ha}^{-1}\left(1.8 \mathrm{~kg}\right.$ of acid equivalent $\left.\mathrm{ha}^{-1}\right)$ of glyphosate. The cover crops biomass was evaluated at soybean and corn sowing.

The soybean 'BRS Valiosa' and corn hybrid BRS 1030 were sown on November 24 (2007), 15 days after herbicide-burning the previous crops. Mulch of cover crops was sampled at the corn and soybean sowing time, for an estimate of straw dry mass. Random samples were taken twice in each plot, with a metallic grid $(25 \mathrm{~cm} \mathrm{x} 25 \mathrm{~cm}$, totaling $625 \mathrm{~cm}^{2}$ ), between the crop rows. The straw samples were dried at $60{ }^{\circ} \mathrm{C}$, until constant weight, to obtain mulch dry mass estimates in $\mathrm{kg} \mathrm{ha}^{-1}$.

Soybean and corn, also referred here as cash crops, were always rainfed. The soil fertilization of cash crops followed recommendations from soil analysis and consisted of $300 \mathrm{~kg} \mathrm{ha}^{-1}$ of the 05-30-15 $\left(\mathrm{N}-\mathrm{P}_{2} \mathrm{O}_{5}-\mathrm{K}_{2} \mathrm{O}\right)$ formulation for corn and $400 \mathrm{~kg} \mathrm{ha}^{-1}$ of 00-20-20 for soybean. Corn seeds were treated with the carbofuran insecticide $(2 \mathrm{~L}$ of the commercial product $100 \mathrm{~kg}^{-1}$ of seeds) and seeds of soybean were inoculated with Biomax (Bradyrhizobium spp. Semia 5079 and 5080 strains with $7.2 \times 10^{9} \mathrm{cfu} \mathrm{g}^{-1}$, $250 \mathrm{~g}$ of commercial product $60 \mathrm{~kg}^{-1}$ of seeds). Cash crops were sown with row spacing of $0.90 \mathrm{~m}$ and $0.45 \mathrm{~m}$ and seeding density of 6.8 and 17 seeds $\mathrm{m}^{-1}$, respectively for corn and soybean. Manual harvest was performed separately, according to the different maturation stages, at 120 and 150 days after emergence, respectively for soybean and corn (Oliveira et al. 2013a, 2013b).

Soil sampling was carried out at the flowering stage of corn and soybean, around 60 days after emergence. Soil samples consisted of eight subsamples taken at the $0-10 \mathrm{~cm}$ topsoil layer from each plot and homogenized manually. The samples were immediately stored in a cooler box with ice and sent for storage in the laboratory for one week $\left(4{ }^{\circ} \mathrm{C}\right)$. The soil samples were used to estimate the soil microbial biomass carbon and nitrogen, soil basal respiration, metabolic quotient and soil enzymatic activity, through hydrolysis of fluorescein diacetate hydrolysis, and the population density of soil fungi.
Microbial biomass carbon was assessed with the fumigation-extraction method by Vance et al. (1987). Briefly, each soil sample was split into six subsamples of $20 \mathrm{~g}$, three of which fumigated for 24 hours with ethanol-free chloroform. Fumigated and non-fumigated samples were incubated for seven days at room temperature $\left(22 \pm 2{ }^{\circ} \mathrm{C}\right)$ in the dark, in individual sealed flasks containing $10 \mathrm{~mL}$ of $1.0 \mathrm{M}$ $\mathrm{NaOH}$. The $\mathrm{CO}_{2}$ released during the incubation period was determined by titration of the residual $\mathrm{NaOH}$, using $0.5 \mathrm{~N} \mathrm{HCl}$ after carbonate precipitation with $\mathrm{BaCl}_{2}$ to estimate soil basal respiration (Jenkinson \& Powlson 1976). Microbial biomass nitrogen was quantified according to Brookes et al. (1985), after sulfuric acid digestion followed by Kjeldahl distillation. The metabolic quotient was estimated as described by Anderson \& Domsch (1990), as was the soil basal respiration /microbial biomass carbon ratio.

Soil enzymatic activity was measured by the fluorescein diacetate hydrolysis method (Schnürer \& Rosswall 1982), and consisted of the dilution of $5 \mathrm{~g}$ of soil in $20 \mathrm{~mL}$ of potassium phosphate buffer (60 mM, pH 7.6) and $0.2 \mathrm{~mL}$ of fluorescein diacetate (Sigma, Cat. No.7378) solution at $2 \mathrm{mg} \mathrm{mL}^{-1}$ of acetone. The samples were shaken for 20 minutes at $170 \mathrm{rpm}$. Afterwards, $2 \mathrm{~mL}$ were taken from the supernatant and added to $2 \mathrm{~mL}$ of acetone, to stop the reaction. The solution was centrifuged for 10 minutes at $170 \mathrm{rpm}$ and then subjected to spectrophotometric analysis at $490 \mathrm{~nm}$.

The density of the soilborne fungi F. solani, F. oxysporum and Trichoderma spp. was quantified by the dilution-plating method, with semi-selective media respectively from Nash \& Snyder (1962), Komada (1975) and Martin (1950). Soil subsamples of $10 \mathrm{~g}$ were diluted at $10^{-2}$ or $10^{-3}$ in distilled water and shaken at $170 \mathrm{rpm}$, for 40 minutes. The deep plating technique was used to mix $1 \mathrm{~mL}$ of soil suspensions to their respective culture media. Rhizoctonia solani density was estimated by the percentage of colonized organic residues in water-agar media (Weinhold et al. 1977). Petri dishes were incubated in the dark for seven days at $20^{\circ} \mathrm{C} \pm 2$, for colony counting.

One-way analysis of variance and Tukey test at $5 \%$ were performed with GLM procedure from the SAS 9.1 statistical software (SAS Institute, Cary, NC, USA). In addition, the principal component analysis (PCA) was carried out to verify the relationship between all soil quality indicators and soil fungi, and to check the relevance of each variable on total 
variance. Cover and cash crops were addressed as supplementary variables to help data analysis, with no influence on the principal components (Lê \& Husson 2008). PCA was carried out with FactoMineR and Rcmdr packages from the R 2.15 statistical software (R Development Core Team, Vienna, Austria).

\section{RESULTS AND DISCUSSION}

The cover crops used here generate different amounts of straw distributed over the soil, as previously reported by Oliveira et al. (2013b). Palisade grass generates $7,792 \mathrm{~kg} \mathrm{ha}^{-1}$, millet $5,371 \mathrm{~kg} \mathrm{ha}^{-1}$ and common bean $4,926 \mathrm{~kg} \mathrm{ha}^{-1}$ of straw. The amount and composition of the cover biomass affected soil quality indicators and soilborne fungi, along with cash crops yield. Millet and common bean provided higher soybean grain yield $\left(4,772 \mathrm{~kg} \mathrm{ha}^{-1}\right.$ and $5,200 \mathrm{~kg} \mathrm{ha}^{-1}$, respectively), while the soybean yield was $3,708 \mathrm{~kg} \mathrm{ha}^{-1}$, when grown after palisade grass (Oliveira et al. 2013a). Corn yield was higher after common bean $\left(8,133 \mathrm{~kg} \mathrm{ha}^{-1}\right)$, differing from millet $\left(6,601 \mathrm{~kg} \mathrm{ha}^{-1}\right)$ and palisade grass $\left(6,801 \mathrm{~kg} \mathrm{ha}^{-1}\right)$ (Oliveira et al. 2013b).

Fluorescein diacetate hydrolysis ranged between 101 and $147 \mathrm{mg}$ of FDA hid kg dry soil ${ }^{-1} \mathrm{~h}^{-1}$, indicating a difference in soil enzymatic activity among the different treatments (Table 1). The soil enzymatic activity was significantly higher for common bean, if compared to palisade grass. There was no difference between corn and soybean crops, considering the averages of soil enzymatic activity, and maize was not affected by the preceding cover crop. Only soybean was responsive to soil enzymatic activity differences among cover crops, with the highest average observed under common bean straw, followed by millet and palisade grass.

Microbial biomass carbon showed significant differences among cash crops, cover crops and their interaction (Table 1). The microbial biomass carbon ranged $100-236 \mathrm{mg} \mathrm{C} \mathrm{kg}^{-1}$ of dry soil, while microbial biomass nitrogen values ranged $37-52 \mathrm{mg} \mathrm{N} \mathrm{kg}^{-1}$ of dry soil. Regarding cash crops, corn yielded the highest average of microbial biomass carbon. Such increase was favored especially in plots previously cropped with palisade grass, in which microbial biomass carbon was $127 \%$ higher than in the common beansoybean sequence. Millet also promoted microbial biomass carbon, which was $53.7 \%$ higher than in the common bean-soybean sequence. In addition, microbial biomass carbon is improved by the cropping of perennial forage species (Stromberger et al. 2007), such as palisade grass, used in this study.

Previous cropping of millet favored higher microbial biomass nitrogen in corn (Table 1), despite the fact that common bean has lower $\mathrm{C}: \mathrm{N}$ ratio and aids endemic soil bacteria (Thébault et al. 2014). According to Nascente et al. (2013), millet residues provide a rapid release of $\mathrm{N}$ to the soil, when compared to palisade grass, what supports our results. There was no difference between corn and soybean, regarding microbial biomass nitrogen. The eventual benefits on nitrogen inputs from cover crops were irrelevant in treatments with soybean, possibly as a result of soybean seeds being inoculated with Bradyrhizobium spp.

Table 1. Soil enzymatic activity (SEA), total microbial activity, carbon (CMB) and nitrogen (NMB) from the microbial biomass, soil basal respiration (SBR) and metabolic quotient $\left(q \mathrm{CO}_{2}\right)$ estimated for cover crops and following cash crops in notillage system.

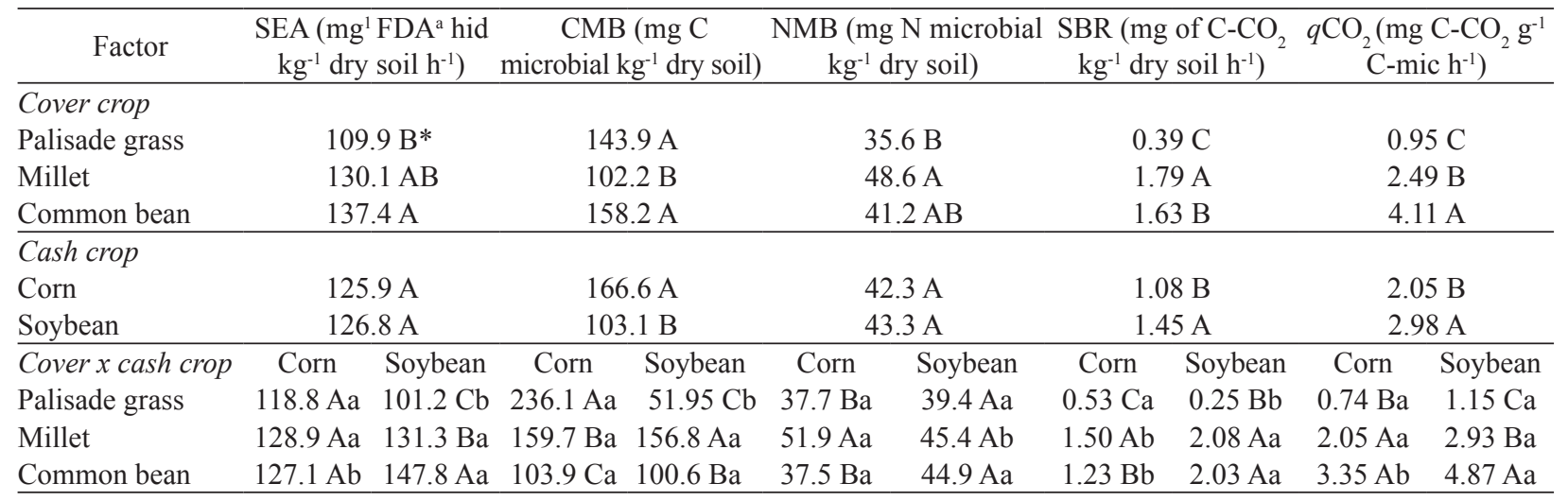

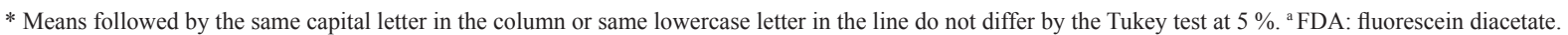


Differences for soil basal respiration and metabolic quotient were observed among cash crops, cover crops and their interaction (Table 1). Palisade grass cropping decreased soil basal respiration and metabolic quotient in both cash crops. On the other hand, the metabolic quotient increased after millet and common bean. These soil biological activity traits increased with soybean cropping, in comparison with corn. Lower metabolic quotient and soil enzymatic activity found in sequences with palisade grass may be related to the higher biomass and lower decay of $U$. brizantha mulch (Oliveira et al. 2013a, 2013b), negatively correlated with general soil microbial activity. Similar results were observed in native vegetation (Ferreira et al. 2010, 2011). In contrast, the higher metabolic quotient observed in the common bean-soybean sequence indicates increased activity of soil microorganisms (Van Bruggen \& Semenov 2000). Some authors, such as Odum (1985), associate increased soil respiration with environmental stress, but, in the present study, we regard soil respiration as an indicator of a transformation ability of the soil microbiota, in response to cropping sequences (Silva et al. 2013).

Palisade grass was unfavorable for Fusarium spp. and $R$. solani, in contrast to millet and common bean (Table 2). The populations of $F$. solani and $F$. oxysporum were higher under soybean, when compared to corn. Regarding cover crops, the highest populations were found under millet for $F$. solani and under common bean for $F$. oxysporum. Mulch and root residues of palisade grass favored increases in the density of the biocontrol agent Trichoderma spp.
(Figure 1), suggesting benefits of such cover crop on the management of fungi associated to root diseases.

The common bean-soybean sequence provided favorable conditions for higher density of $R$. solani, in contrast to the treatments with millet or palisade grass. The present results showed that $R$. solani was the fungal species that best supported the increased soil activity, in contrast to Trichoderma spp. Naturally, many other fungal or bacterial species might have responded to the treatments studied here, but our study was restricted to the relationships among Fusarium, Rhizoctonia and Trichoderma and soil quality indicators. Furthermore, palisade grass straw was the only effective cover crop to significantly decrease, in the short-term, all fungal populations related to root

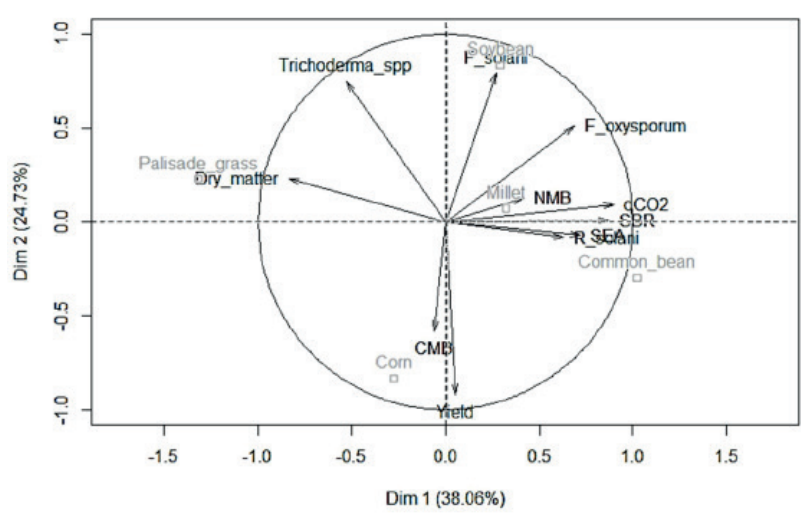

Figure 1. PCA biplot with relationships found in the first two components, between soil quality indicators and soilborne fungi, assessed in a no-tillage system. Cover crops (palisade grass, millet and common bean) and cash crops (soybean and corn) were addressed as supplementary variables.

Table 2. Effects of cover crops and cash crops on soilborne fungal population in no-tillage system.

\begin{tabular}{|c|c|c|c|c|c|c|c|c|}
\hline \multirow{2}{*}{ Factor } & \multicolumn{2}{|c|}{ Fusarium solani } & \multirow{2}{*}{\multicolumn{2}{|c|}{$\begin{array}{c}\text { Fusarium oxysporum } \\
\text { aPPG x } 1.000\end{array}$}} & \multicolumn{2}{|c|}{ Trichoderma spp. } & \multirow{2}{*}{\multicolumn{2}{|c|}{$\begin{array}{c}\text { Rhizoctonia solani } \\
\text { b\% ORC }\end{array}$}} \\
\hline & \multicolumn{4}{|c|}{ aPPG x 1,000} & & & & \\
\hline \multicolumn{7}{|l|}{ Cover crop } & \\
\hline Palisade grass & \multicolumn{2}{|c|}{$3.70 \mathrm{~B} *$} & \multicolumn{2}{|c|}{$2.78 \mathrm{~B}$} & \multicolumn{2}{|c|}{$9.28 \mathrm{~A}$} & \multicolumn{2}{|c|}{$2.49 \mathrm{~B}$} \\
\hline Millet & \multicolumn{2}{|c|}{$5.03 \mathrm{~A}$} & \multicolumn{2}{|c|}{$3.80 \mathrm{~A}$} & \multicolumn{2}{|c|}{ 4.20 B } & \multicolumn{2}{|c|}{$4.99 \mathrm{AB}$} \\
\hline Common bean & \multicolumn{2}{|c|}{$3.00 \mathrm{~B}$} & \multicolumn{2}{|c|}{$4.68 \mathrm{~A}$} & \multicolumn{2}{|c|}{$0.93 \mathrm{C}$} & \multicolumn{2}{|c|}{$10.55 \mathrm{~A}$} \\
\hline \multicolumn{9}{|l|}{ Cash crop } \\
\hline Corn & \multicolumn{2}{|c|}{$2.22 \mathrm{~B}$} & \multirow{2}{*}{\multicolumn{2}{|c|}{$\begin{array}{l}2.15 \mathrm{~B} \\
5.22 \mathrm{~A}\end{array}$}} & \multirow{2}{*}{\multicolumn{2}{|c|}{$\begin{array}{l}1.47 \mathrm{~B} \\
8.13 \mathrm{~A}\end{array}$}} & \multicolumn{2}{|c|}{$4.62 \mathrm{~A}$} \\
\hline Soybean & \multicolumn{2}{|c|}{$5.60 \mathrm{~A}$} & & & & & \multicolumn{2}{|c|}{$7.40 \mathrm{~A}$} \\
\hline Cover crop $x$ cash crop & Corn & Soybean & Corn & Soybean & Corn & Soybean & Corn & Soybean \\
\hline Palisade grass & $2.60 \mathrm{Ab}$ & $4.80 \mathrm{Ba}$ & $2.05 \mathrm{Ba}$ & $3.10 \mathrm{Ca}$ & $0.75 \mathrm{Ab}$ & $17.80 \mathrm{Aa}$ & $3.33 \mathrm{Aa}$ & $1.66 \mathrm{Ba}$ \\
\hline Millet & $3.05 \mathrm{Ab}$ & $7.00 \mathrm{Aa}$ & $3.20 \mathrm{Ab}$ & $4.40 \mathrm{Ba}$ & $2.35 \mathrm{Ab}$ & $6.05 \mathrm{Ba}$ & $3.33 \mathrm{Aa}$ & 6.66 Aba \\
\hline Common bean & $1.00 \mathrm{Bb}$ & $5.00 \mathrm{Ba}$ & $1.20 \mathrm{Bb}$ & $8.15 \mathrm{Aa}$ & $1.30 \mathrm{Aa}$ & $0.55 \mathrm{Ca}$ & $7.22 \mathrm{Aa}$ & $13.88 \mathrm{Aa}$ \\
\hline
\end{tabular}


diseases in soybean. Population decline is one of the mechanisms of soilborne pathogen control based on crop residues (Bonanomi et al. 2010). Even though pathogenicity tests were not carried out here, the implementation of no-tillage with palisade grass is expected to help the management of $R$. solani and F. oxysporum (Toledo-Souza et al. 2008).

Despite the relevant benefits of palisade grass in decreasing pathogen populations, it is important to note that it decreased the subsequent soybean yield in crop rotation (Oliveira et al. 2013a). It is unclear what are the factors that lead to soybean decreased leaf area index and number of pods per plant, resulting in lower yield after palisade grass crop rotation.

Principal component analysis indicated clear differences between effects provided by cover and cash crops on soil quality indicators and fungi density, in which $76.61 \%$ of the variance was explained by the three main components $(38.06 \%, 24.73 \%$ and $13.82 \%$ ) (Figure 1). The multivariate approach attended the recommendations by Janvier et al. (2007) to identify soil health indicators. Cover crops had a higher correlation (0.72) with the first component, while cash crops were mostly correlated $(0.81)$ with the second principal component (Table 3). As the microbial activity variables were mostly correlated with PC1, these correlations indicate that mulch might have a stronger influence on microbiological density and activity than cash crops.

Table 3. Results of the principal component analysis including cover crops, cash crops, soil quality indicators and soilborne fungi assessed in no-tillage system, with significance of $p<0.05$.

\begin{tabular}{lccc}
\hline \multicolumn{1}{c}{ Variable } & PC1 & PC2 & PC3 \\
\hline Eigenvalue & 4.20 & 2.70 & 1.50 \\
\% of variance & 38.06 & 24.73 & 13.82 \\
\% of cumulative variance & 38.06 & 62.79 & 76.61 \\
Cover crop $^{\mathrm{a}}$ & 0.72 & $\mathrm{~ns}$ & 0.38 \\
Cash crop $^{\mathrm{b}}$ & $\mathrm{ns}$ & 0.81 & $\mathrm{~ns}$ \\
Yield $^{\mathrm{ns}}$ & -0.92 & $\mathrm{~ns}$ \\
Dry matter (mulch) & -0.83 & $\mathrm{~ns}$ & $\mathrm{~ns}$ \\
Soil enzymatic activity & 0.72 & $\mathrm{~ns}$ & $\mathrm{~ns}$ \\
Microbial biomass carbon & $\mathrm{ns}$ & -0.57 & 0.66 \\
Microbial biomass nitrogen & 0.41 & $\mathrm{~ns}$ & 0.68 \\
Soil basal respiration & 0.87 & $\mathrm{~ns}$ & $\mathrm{~ns}$ \\
Metabolic quotient & 0.90 & $\mathrm{~ns}$ & $\mathrm{~ns}$ \\
Fusarium solani & $\mathrm{ns}$ & 0.79 & 0.41 \\
Fusarium oxysporum & 0.68 & 0.51 & $\mathrm{~ns}$ \\
Trichoderma spp. & -0.52 & 0.74 & $\mathrm{~ns}$ \\
Rhizoctonia solani & 0.63 & $\mathrm{~ns}$ & $\mathrm{~ns}$ \\
\hline a palisade grass, millet and common bean; ${ }^{\mathrm{b}}$ corn and soybean. &
\end{tabular}

There were positive correlations of soil enzymatic activity, microbial biomass nitrogen, basal soil respiration, metabolic quotient, $F$. oxysporum and $R$. solani with the first principal component $(\mathrm{p}<0.05)$, while dry matter and Trichoderma spp. were negatively associated with PC1 (Table 3). Fusarium species and Trichoderma spp. were associated with PC2, while yield and microbial mass carbon were negatively correlated with the second principal component of the PCA.

As aforementioned, the balance between putative pathogens and antagonists is not easily controlled and depends on several factors that include chemical and physical variables, in addition to changes in the soil microbial community (Pérez-Piqueres et al. 2006, Toledo-Souza et al. 2008). Such balance is expected to change with cumulative effects of cover crops, if no-tillage is maintained in a cropping system. For this reason, the correlations of soil quality indicators with the inoculum density of pathogens and antagonists reported here demonstrate immediate effects in the first year after the implementation of the no-tillage system. Long-term trials are recommended to investigate further consequences that might affect decisions for crop management in a conservationist approach (Table 3).

Although many soil fungi and bacteria affect soil suppressiveness to root diseases, some endemic species may have a key role over soil pathogens (Liu \& Baker 1980). In our study, relevant soil fungi were affected by cover crops, and palisade grass favored Trichoderma spp., in contrast to $R$. solani. These results reinforce the recommendations of palisade grass to the management of soilborne pathogens in no-tillage systems (Toledo-Souza et al. 2008). Palisade grass is a well-known grass for pastures under tropical climate, because of the high dry matter yield, lignin content and $\mathrm{C} / \mathrm{N}$ ratio and low decomposition rate. It is one of the main sources of mulch to no-tillage systems, in Brazil (Nascente et al. 2013, Oliveira et al. 2013a, 2013b).

This study showed correlations among soil quality indicators, soilborne fungi, yield and both cover and cash crops. Agronomic practices required for crop management, such as grass herbicideburning and common bean manual harvest, may affect plant $\times$ soil $\times$ microorganism relationships, and therefore treatment effects discussed here rely not only on the crop itself, but also on standard cropping methods. Apparently, these results are the first ones on the relationships among microbial biomass 
carbon and nitrogen and soil enzymatic activity with Trichoderma spp. and Fusarium spp. They are in agreement with Bonanomi et al. (2010), regarding the positive correlation between soil respiration and $R$. solani and the beneficial effects of crop residues on this pathogen suppression.

Besides the increment of endemic Trichoderma spp., it is possible that a high $\mathrm{C} / \mathrm{N}$ ratio and lignin content of palisade grass promote other suppression mechanisms of $R$. solani, such as beneficial Streptomyces spp. and basidiomycetes responsible to microsclerotia decay (Postma et al. 2008, Van Beneden et al. 2010). Changes in the microbial community can improve fungistasis and decrease populations of some pathogens. It is noteworthy that the increase of soil basal respiration was related to cover crops with lower $\mathrm{C} / \mathrm{N}$ ratio (Table 1 ), where faster straw decomposition rate and loss of $\mathrm{CO}_{2}$ in common bean and millet might have changed soil fungistasis based on the competition hypothesis (Bonanomi et al. 2013).

Our results described how the sequences of cover crops and cash crops in one agricultural year affect the balance between different soil biological attributes, in a tropical region. Regardless of differences in temperature and rainfall, they also match the literature from countries with Mediterranean or temperate climate (Termorshuizen et al. 2006, Bonanomi et al. 2013). It is possible that different responses from fungal species and microbial processes arise in long-term sequences, and microbial community structure and other indicators could provide further relevant information on soil health.

Among the different cover crops assessed here, palisade grass is recommended as the best option for soybean and maize crop management, since it provides higher amount of dry mass and is likely to keep long-lasting mulch on the soil surface (Nascente et al. 2013). Besides the benefits on soil and water conservation, palisade grass straw minimizes soil microbiological activity and might help the management of fungal soilborne pathogens.

\section{CONCLUSIONS}

1. Crop sequences in a no-tillage system affect the balance between different soil biological attributes.

2. Palisade grass minimizes soil microbial activity and might favor soil health with increase of endemic Trichoderma spp.
3. Common bean and millet are positively associated with higher density of $R$. solani and $F$. oxysporum and increased microbial activity (soil basal respiration, metabolic quotient and soil enzymatic activity).

\section{ACKNOWLEDGMENTS}

Authors are grateful to the Coordenação de Aperfeiçoamento de Pessoal de Nível Superior (Capes) and Conselho Nacional de Desenvolvimento Científico e Tecnológico $(\mathrm{CNPq})$, respectively for a graduate scholarship to Priscila Oliveira and a research grant (578604/2008-6) to Murillo Lobo Junior.

\section{REFERENCES}

ANDERSON, T. H.; DOMSCH, K. H. Application of ecophysiological quotients $\left(q \mathrm{CO}_{2}\right.$ and $\left.\mathrm{qD}\right)$ on microbial biomasses from soils of different cropping histories. Soil Biology \& Biochemistry, Oxford, v. 22, n. 2, p. 251-255, 1990.

ANDERSON, T. H.; DOMSCH, K. H. Ratios of microbial biomass carbon to total organic carbon in arable soils. Soil Biology \& Biochemistry, Oxford, v. 21, n. 4, p. 471-479, 1989.

ANEES, M.; EDEL-HERMANN, V.; STEINBERG, C. Buildup of patches caused by Rhizoctonia solani. Soil Biology \& Biochemistry, Oxford, v. 42, n. 10, p. 16611672, 2010.

BONANOMI, G. et al. Biochemical quality of organic amendments affects soil fungistasis. Applied Soil Ecology, Amsterdam, v. 72, n. 1, p. 135-142, 2013.

BONANOMI, G. et al. Identifying the characteristics of organic soil amendments that suppress soilborne plant diseases. Soil Biology \& Biochemistry, Oxford, v. 42, n. 2, p. 136-144, 2010.

BROOKES, P. C. et al. Chloroform fumigation and the release of soil nitrogen, a rapid direct extraction method to measure microbial biomass nitrogen in soil. Soil Biology \& Biochemistry, Oxford, v. 17, n. 6, p. 837-842, 1985.

FERREIRA, E. P. B. et al. Microbial soil quality indicators under different crop rotations and tillage management. Revista Ciência Agronômica, Fortaleza, v. 41, n. 2, p. 177183, 2010.

FERREIRA, E. P. B.; WENDLAND, A.; DIDONET, A. D. Microbial biomass and enzyme activity of a Cerrado Oxisol under agroecological production system. Bragantia, Campinas, v. 70, n. 4, p. 899-907, 2011.

GARBEVA, P.; VAN VEEN, J. A.; VAN ELSAS, J. D. Microbial diversity in soil: selection of microbial 
populations by plant and soil type and implications for disease suppressiveness. Annual Review of Phytopathology, Palo Alto, v. 42, n. 1, p. 243-270, 2004.

JANVIER, C. et al. Soil health through soil disease suppression: which strategy from descriptors to indicators? Soil Biology \& Biochemistry, Oxford, v. 39, n. 1, p. 1-23, 2007.

JENKINSON, D. S.; POWLSON, D. S. The effects of biocidal treatments on metabolism in soil: V. A method for measuring soil biomass. Soil Biology \& Biochemistry, Oxford, v. 8, n. 3, p. 209-213, 1976.

KASCHUK, G.; ALBERTON, O.; HUNGRIA, M. Three decades of soil microbial biomass studies in Brazilian ecosystems: lessons learned about soil quality and indications for improving sustainability. Soil Biology \& Biochemistry, Oxford, v. 42, n. 1, p. 1-13, 2010.

KNUPP, A. M.; FERREIRA, E. P. B. Eficiência da quantificação do carbono da biomassa microbiana por espectrofotometria comparada ao método titrimétrico. Revista Brasileira de Ciências Agrárias, Recife, v. 6, n. 4, p. 588-595, 2011.

KOMADA, H. Development of a selective medium for quantitative isolation of Fusarium oxysporum from natural soils. Review of Plant Protection Research, Tokyo, v. 8, n. 1, p. 114-125, 1975

LÊ, S.; HUSSON, F. FactorMineR: an R package for multivariate analysis. Journal of Statistical Software, Los Angeles, v. 25, n. 1, p. 1-18, 2008.

LIU, S.; BAKER, R. Mechanisms of biological control in soil suppressive to Rhizoctonia solani. Phytopathology, Saint Paul, v. 70, n. 5, p. 404-412, 1980.

MARTIN, J. P. Use of acid, rose bengal and streptomycin in the plate method for estimating soil fungi. Soil Science, Philadelphia, v. 69, n. 3, p. 215-232, 1950.

MOREIRA, F. M. S.; SIQUEIRA, J. O. Microbiologia e bioquímica do solo. 2. ed. Lavras: UFLa, 2006.

NASCENTE, A. S.; CRUSCIOL, C. A. C.; COBUCCI, T. The no-tillage system and cover crops: alternatives to increase upland rice yields. European Journal of Agronomy, Amsterdam, v. 45, n. 2, p. 124-131, 2013.

NASH, S. M.; SNYDER, W. C. Quantitative estimations by plate counts of propagules of the beans root rot Fusarium in field soil. Phytopathology, Saint Paul, v. 52, n. 6, p. 567-572, 1962.

ODUM, E. P. Trends expected in stressed ecosystems. BioScience, Athens, v. 35, n. 7, p. 419-422, 1985.

OLIVEIRA, P. et al. Crescimento e produtividade de milho em função da cultura antecessora. Pesquisa Agropecuária Tropical, Goiânia, v. 43, n. 3, p. 239-246, 2013 b.

OLIVEIRA, P.; NASCENTE, A. S.; KLUTHCOUSKI, J. Soybean growth and yield under cover crops. Revista Ceres, Viçosa, v. 60, n. 2, p. 249-256, 2013 a.

PANKHURST, C. E. et al. Evaluation of soil biological properties as potential bioindicators of soil health.
Australian Journal of Experimental Agriculture, Collingwood, v. 35, n. 7, p. 1015-1028, 1995.

PÉREZ-PIQUERES, A. et al. Response of soil microbial communities to compost amendments. Soil Biology \& Biochemistry, Oxford, v. 38, n. 3, p. 460-470, 2006.

POSTMA, J. et al. Soil suppressiveness and functional diversity of the soil microflora in organic farming systems. Soil Biology \& Biochemistry, Oxford, v. 40, n. 9, p. 23942406, 2008

SCHNÜRER, J.; ROSSWALL, T. Fluorescein diacetate hydrolysis as a measure of total microbial activity in soil and litter. Applied and Environmental Microbiology, Washington, DC, v. 43, n. 6, p. 1256-1261, 1982.

SILVA, M. C. P. e et al. Microbe-mediated processes as indicators to establish the normal operating range of soil functioning. Soil Biology \& Biochemistry, Oxford, v. 57, n. 2, p. 995-1002, 2013.

STROMBERGER, M.; SHA, Z.; WESTFALL, D. Soil microbial communities of no-till dryland agroecosystems across an evapotranspiration gradient. Applied Soil Ecology, Amsterdam, v. 35, n. 1, p. 94-106, 2007.

TERMORSHUIZEN, A. J. et al. Suppressiveness of 18 composts against 7 pathosystems: variability in pathogen response. Soil Biology \& Biochemistry, Oxford, v. 38, n. 8, p. 2461-2477, 2006.

THÉBAULT, A. et al. Nitrogen limitation and microbial diversity at the treeline. Oikos, Hoboken, v. 126, n. 6, p. 729-740, 2014.

TOLEDO-SOUZA, E. D. et al. Sistemas de cultivo, sucessões de culturas, densidade do solo e sobrevivência de patógenos de solo. Pesquisa Agropecuária Brasileira, Brasília, DF, v. 43, n. 8, p. 971-978, 2008.

VAN BENEDEN, S. et al. Microbial populations involved in the suppression of Rhizoctonia solani AG1-1B by lignin incorporation in soil. Soil Biology \& Biochemistry, Oxford, v. 42, n. 8, p. 1268-1274, 2010.

VAN BRUGGEN, A. H.; SEMENOV, A. V. In search of biological indicators for soil health and disease suppression. Applied Soil Ecology, Amsterdam, v. 15, n. 1, p. 13-24, 2000.

VANCE, E. D.; BROOKES, P. C.; JENKINSON, D. S. An extraction method for measuring soil microbial biomass $\mathrm{C}$. Soil Biology \& Biochemistry, Oxford, v. 19, n. 6, p.703707, 1987.

VEEKEN, A. H. M. et al. Improving quality of composted biowaste to enhance disease suppressiveness of compostamended, peat-based potting mixes. Soil Biology \& Biochemistry, Oxford, v. 37, n. 11, p. 2131-2140, 2005.

WEINHOLD, A. R. et al. Population of Rhizoctonia solani in agricultural soils determined by a screening procedure. Phytopathology, Saint Paul, v. 67, n. 4, p. 566-569, 1977.

WELLER, D. M. et al. Microbial populations responsible for specific soil suppressiveness to plant pathogens. Annual Review of Phytopathology, Palo Alto, v. 40, n. 1, p. 309348, 2002. 